\title{
Applied Entomology and Zoology Vol. 49, No. 4 目次
}

(2014 年 11 月 25 日発行)

\section{ORIGINAL RESEARCH PAPERS}

Development and parasitization of an aphid's secondary parasitoid, Dendrocerus laticeps (Hymenoptera: Megaspilidae), on Aphidius colemani (Hymenoptera: Braconidae)

T. Mitsunaga $\cdot$ K. Nagasaka $\cdot$ S. Moriya 511

[コレマンアブラバチ Aphidius colemani (ハチ目：コマユバチ科) の二次寄生蜂 Dendrocerus laticeps (ハチ目：オオモンクロバチ科) の発育期間と寄生能力

光永貴之・長坂幸吉・守屋成一］511

Effect of multiple mating on the reproductive performance of the rice leaffolder moth, Cnaphalocrocis medinalis (Lepidoptera: Crambidae)

K. Kawazu • Y. Shintani - S. Tatsuki 519

[コブノメイガ Cnaphalocrocis medianalis (チョウ目：ツトガ科) の生殖に対する多数回交尾の影響

河津 圭·新谷喜紀 ·田付貞洋] 519

Pars intercerebralis promotes oviposition in the bean bug, Riptortus pedestris (Heteroptera: Alydidae)

K. Shimokawa $\cdot$ H. Numata $\cdot$ S. Shiga $\mathbf{5 2 5}$

[ホソヘリカメムシ Riptortus pedestris（カメムシ目：ホソヘリカメ ムシ科)の産卵に打ける脳間部の役割

下川佳代·沼田英治·志賀向子］ 525

Rapid development of resistance to diamide insecticides in the smaller tea tortrix, Adoxophyes honmai (Lepidoptera: Tortricidae), in the tea fields of Shizuoka Prefecture, Japan

T. Uchiyama $\cdot$ A. Ozawa $\mathbf{5 2 9}$

[静岡県のチャ園に打けるチャノコカクモンハマキAdoxophyes honmai (チョウ目：ハマキガ科) のジアミド系殺虫剤に対する急 速な抵抗性の発達

内山 徹・小澤朗人］ 529

Development of neonicotinoid resistance in the cotton aphid Aphis gossypii (Hemiptera: Aphididae) in Japan

A. Matsuura • M. Nakamura $\mathbf{5 3 5}$

[日本に打けるネオニコチノイド剤抵抗性ワタアブラムシ Aphis gossypii (カメムシ目：アブラムシ科)の初確認

松浦 明・中村正和] 535
New records of Megaselia (Diptera: Phoridae) reared from fungus sporophores in Japan, including five new species

R. H. L. Disney · M. Nitta • M. Kobayashi · N. Tuno 541

[5 新種を含むキノコから羽化した日本産 Megaselia 属 (八エ目：

ノミバエ科) 8 種の新記録

R. Henry L. Disney · 新田真之 ·小林美緒・都野展子］ 541

Preliminary evaluation of greenhouses employing positivepressure forced ventilation to prevent invasion by insect pests

K. Sugiyama $\cdot$ N. Ohishi $・$ T. Saito 553

[害虫の侵入を抑制する陽圧式強制換気温室の予備的評価

杉山恵太郎·大石直記·西東 力 $] 553$

Factors that affect the selection of tomato leaflets by two whiteflies, Trialeurodes vaporariorum and Bemisia tabaci (Homoptera: Aleyrodidae)

H. Tsueda ・ T. Tsuduki $・$ K. Tsuchida $\mathbf{5 6 1}$

[オンシツコナジラミ Trialeurodes vaporariorum とタバココナジラ

ミBemisia tabaci (カメムシ目：コナジラミ科) が定位するトマト 葉の選択に影響する要因について

杖田浩二・都築＼cjkstart朋・土田浩治］561

Comparisons of accumulation and excretion of iminosugars among mulberry-feeding specialist Bombyx larvae and non-specialist larvae

M. Hori $\cdot$ S. Komatsubara $\cdot$ K. Nakagawa $\cdot$ O. Higuchi $\cdot$ S. Onose $\cdot$ T. Miyazawa 571

[クワ食スペシャリスト幼虫 (Bombyx) と非スペシャリスト幼虫 との間のアザ糖類の蓄積と排泄の比較

堀 雅敏 · 小松原慈人 · 仲川清隆 · 樋口央紀 - 小野瀬晋司 · 宮澤 陽夫］ 571

A mathematical model for the territorial competition of the subterranean termites Coptotermes formosanus and Reticulitermes flavipes (Isoptera: Rhinotermitidae)

W. Jeon $\cdot$ S.-H. Lee $\mathbf{5 7 9}$

[地下棲息性のイエシロアリCoptotermes formosanus と Reticulitermes flavipes (シロアリ目：ミゾガシラシロアリ科)に拉 ける縄張り競争をめぐる数理モデル

Wonju Jeon • Sang-Hee Lee ] 579 
Effects of the veterinary antiparasitic drug eprinomectin on dung beetles (Coleoptera: Scarabaeidae), the non-pest fly Neomyia cornicina and pest fly Haematobia irritans (Diptera: Muscidae) in Japan

M. Iwasa - M. Sugitani 591

[牛用駆虫剤エプリノメクチンが非標的昆虫の食粪性コガネムシ 2 種 (コウチュウ目：コガネムシ科) とキタミドリイエバエNeomyia cornicina 扩よび吸血性ノサシバエ Haematobia irritans（ハエ目： イエバエ科)に及ぼす影響

岩佐光啓・杉谷美乃里］591

Non-consumptive effects of the predatory beetle Delphastus catalinae (Coleoptera: Coccinellidae) on habitat use patterns of adult whitefly Bemisia argentifolii (Hemiptera: Aleyrodidae)

D.-H. Lee • J. P. Nyrop • J. P. Sanderson 599

[シルバーリーフコナジラミ（タバココナジラミ・バイオタイプ

B) Bemisia argentifolii (カメムシ目 : コナジラミ科) 成虫の植物内 生息パターンはテントウムシ科の捕食者Delphastus catalinae (コ ウチュウ目：テントウムシ科) の存在で変化する

Doo-Hyung Lee • Jan P. Nyrop • John P. Sanderson] 599

\section{TECHNICAL NOTES}

Plantago asiatica groundcover supports Amblyseius tsugawai (Acari: Phytoseiidae) populations in apple orchards

K. Funayama $\cdot$ S. Sonoda $\mathbf{6 0 7}$

[リンゴ園でオオバコはミチノクカブリダニ Amblyseius tsugawai (ダニ目：カブリダニ科)を保護する

舟山 健 ·園田昌司] 607
Rapid microsatellite marker isolation for the Pink Stem Borer, Sesamia inferens (Lepidopetera: Noctuidae), through 454 GS-FLX Titanium pyrosequencing of enriched DNA libraries and cross amplification in related taxa

Y. Liu $\cdot$ X. An · M. Hou 613

[イネヨトウSesamia inferens (チョウ目：ヤガ科)に打けるロシュ 454 シーケンサーを用いた高速マイクロサテライトマーカー探索 と近縁分類群における交差増幅

Yudi Liu $\cdot$ Xingkui An · Maolin Hou] 613

Polymorphic microsatellite markers in Thrips hawaiiensis (Thysanoptera: Thripidae)

Y. Wu $\cdot$ K. Liu $\cdot$ H. Qiu F. Li • Y. Cao 619

[ハナアザミウマThrips hawaiiensis (アザミウマ目:アザミウマ科)

における多型的マイクロサテライトマーカー

Yi Wu $\cdot$ Kui Liu $\cdot$ Haiyan Qiu $\cdot$ Fujun Li • Yang Cao〕 619

Isolation and validation of eight microsatellite loci in a damselfly Ischnura senegalensis (Odonata: Coenagrionidae) by pyrosequencing a bead-enriched library

T. Kurita $\cdot$ H. Aoyama $\cdot$ S. Saitoh $\cdot$ N. Shinzato $\cdot$ K. Sawada $\cdot$ T. Kuriwada $\cdot$ K. Hironaka $\cdot$ N. Inomata $\cdot$ K. Yamahira $\cdot$ M. Toda 623

[ビーズ濃縮ライブラリーのパイロシーケンシングによるアオモ ンイトトンボIschnura senegalensis (トンボ目：イトトンボ科）か らの 8 マイクロサテライト遺伝子座の単離

栗田隆気 · 青山洋昭 - 齋藤星耕 - 新里尚也 - 澤田浩司 - 栗和田 隆·弘中玖美子·猪股伸幸・山平寿智・戸田 守］ 623 